\title{
Spend more to compete
}

\section{London}

A NEW £10-million-a-year fund should be set up to help British universities meet the overhead costs of research projects supported by grants from the European Communities (EC), according to a crossparty House of Commons committee.

But the Education, Science and Arts (ES\&A) Committee's report on the European dimension of British science policy says there is no need for a cabinet-level science minister to represent the interests of British science in Europe - an issue expected to loom large in a major inquiry into British science policy launched last week by the Royal Society (see below).

British academics appear to be successful in winning grants from the EC's SCIENCE programme for basic research, recovering more money than Britain contributes to the programme. The ES\&A committee seems to have been persuaded by a succession of witnesses that the universities contribute more towards the indirect costs of European research projects than towards those supported by British research council grants. In most other EC countries, the overhead costs of EC research projects are met largely by individual governments, which puts British researchers at a disadvantage.

This claim was accepted by the ES\&A committee, whence its recommendation of the new fund, to be run by the Advisory Board for the Research Councils. The committee would provide universities and polytechnics with an extra $20-30$ per cent of the value of $\mathrm{EC}$ grants received, which would at present amount to $£ 10$ million of new money a year.

But if UK academics are disadvantaged in accepting EC grants by the burden of overheads, why do British scientists submit more applications to the SCIENCE programme than those from any other EC member state?

One reason may be that the British domestic science budget is too small, forcing UK academics to turn to the EC for support. The ES\&A committee urges the government to increase its spending on civil science by 50 per cent, to match the proportion of gross domestic product spent in France and Germany.

This plea is unlikely to be accepted by the British Treasury, whose tightening of the public purse-strings has already precipitated a financial crisis for the research councils (see Nature 348, 377; 29 November 1990).

The ES\&A committee's report also attacks the Treasury's practice of 'attribution' - that of subtracting a proportion of the money won by British scientists from EC research programmes from the following year's domestic spending on science. In this respect, the

ES\&A committee echoes the earlier criticisms of the House of Lords EC committee (see Nature 346, 305; 1990).

Many British scientists hold that the UK scientific community has too little influence when $\mathrm{EC}$ research programmes are drawn up. Britain is represented at meetings of $E C$ research ministers by an industry minister, currently Lord Hesketh. Although briefed by officials from the Department of Education of Science (DES), some of the committee's witnesses argued that an industry minister could not adequately represent British academics.

The report says that the DES minister responsible for basic science, currently Alan Howarth, should also attend meetings of EC research ministers, but says UK SCIENCE POLICY

\section{Royal Society announces policy inquiry}

that a separate cabinet minister to coordinate British science is not necessary. Indeed, the committee argues that a new ministry of science would be inappropriate, cutting across the need that most UK government departments should also have a strong science base. The committee also says that a minister with merely a coordinating function and no departmental budget may lack real influence over policy decisions.

The debate over the value of cabinet representation for British science, which has intensified since the departure of Margaret Thatcher as prime minister, will not be silenced by the ES\&A committee's report. The Save British Science pressure group has made the appointment of a cabinet-level science minister one of its targets. This issue is also likely to feature in the Royal Society's inquiry into British science policy.

Peter Aldhous

\section{London}

THE Royal Society announced last week that it is to carry out a wide-ranging inquiry into the conduct of science policy in Britain. The inquiry could be particularly influential, coming as it does so

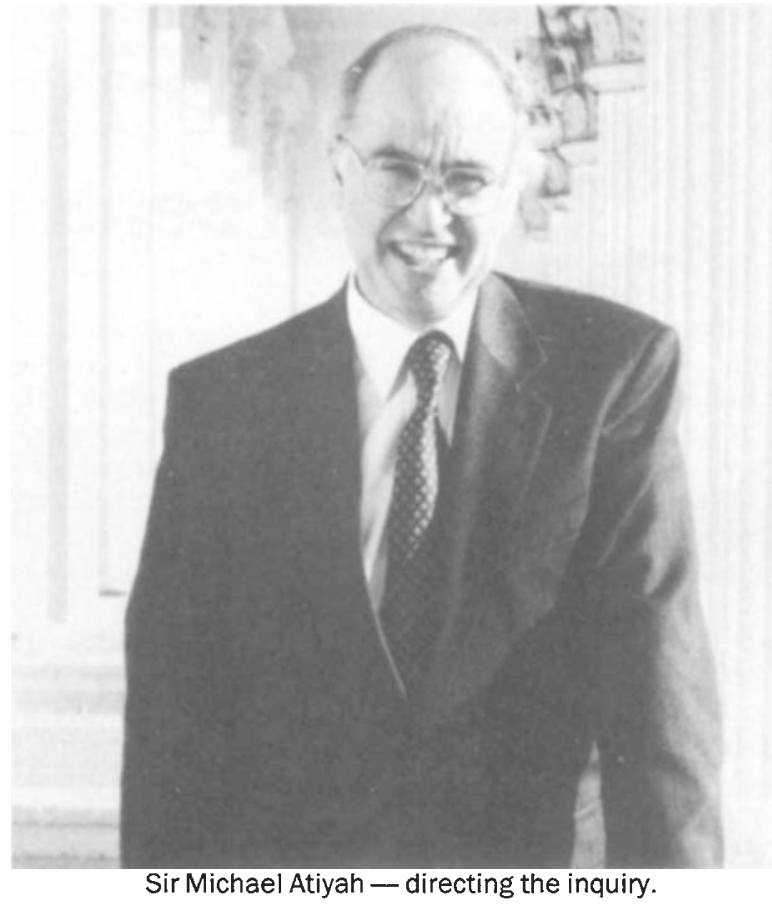

public before then.

Among other things, according to Brian Follett, biological secretary of the Royal Society, the inquiry will probably weigh the advantages and disadvantages of a cabinet-rank minister. Follett would like to see cabinet representation for science, provided that the minister concerned is given a suitable agenda.

But Sir Francis GrahamSmith, the society's physical secretary, remains unconvinced, unless a cabinet appointment is the only way to achieve reform of the damaging practice of attribution for $\mathrm{EC}$ research spending against the Department of Education and Science science budget (see above).

The Royal Society's inquiry will encompass most aspects of UK science policy, and has been prompted by a number of changes over the 1980 s including the increasing proportion of researchers on short-term contracts, the declining proportion of soon after the change of prime minister and at a time when British connections with the European mainland will be further strengthened after 1992.

The work will be directed by a team of eight fellows of the Royal Society under the chairmanship of Sir Michael Atiyah, president of the society since the end of last November. A final report of the inquiry is expected sometime in early 1992, but findings on specific issues may be made research financed by government and the expansion of international collaboration. PeterAldhous

- The meeting between Prime Minister John Major and a delegation of prominent British scientists, planned for 14 January, has been postponed because of the crisis in the Gulf. The delegation, led by Conservative MP Sir Ian Lloyd, is expected to argue for a new deal for British science, including representation in the cabinet. 